\title{
A PROCURA DO JESUS HISTÓRICO
}

\section{ARTIGO ORIGINAL}

FARAH, Leonardo de Castro ${ }^{1}$

FARAH, Leonardo de Castro. A procura do Jesus histórico. Revista Científica Multidisciplinar Núcleo do Conhecimento. Ano 05, Ed. 05, Vol. 07, pp. 35-61. Maio de 2020. ISSN: 2448-0959, Link de acesso: https://www.nucleodoconhecimento.com.br/ciencia-da-religiao/jesushistorico

\section{RESUMO}

Nossa pesquisa concentra-se nos períodos iniciais do cristianismo, chamado pelos estudiosos de período paleocristão. Nosso estudo focou entre a época da morte de Jesus até a 1르 Guerra Judaica, que se deu nos anos de 30 até o ano 65 d. C. Encontrar o Jesus Histórico é uma tarefa árdua, pois é muito difícil ter acesso à dados confiáveis. Essa dificuldade seria devido à falta de documentos históricos e arqueológicos que comprovam sua existência. Tanto Tácito como Suetônio comentaram, em sua obra, sobre a existência de uma seita dos seguidores de "Crestos". Porém, os escritores romanos não confirmaram a existência de Jesus. Além do mais, entre o século I a. C e o século I d. C teve-se um período marcado pelo surgimento de diversos milagreiros que viveram na região do Levante. Neste quesito temos: os Essênios, Apolônio de Tiana, Simão de Pereia, Honi, O Desenhador de Círculos e Hanina Ben Dosa, além do próprio Jesus. Já os milagres, a natividade e a morte e ressurreição atribuída a Jesus eram semelhantes ao que existe na mitologia greco-romana e de outros deuses da antiguidade que são centenas de anos mais antigos que os relatos dos Evangelhos.

\footnotetext{
${ }^{1}$ Graduado em História pela UNI-BH. Especialista em Educação em Sociologia pela Faculdade Noroeste de Minas Gerais. Especialista em História pela Faculdade Lusobrasileira. Especialista em História e Geografia pelo Centro Universitário Barão de Mauá.
} 
Por isso, não podemos tomar como fatos históricos alguns dos eventos narrados nos Evangelhos, pois, apesar de se completarem, também são contraditórios. Além do mais, a mensagem de Jesus é muito semelhante à filosofia dos Essênios e das filosofias clássicas: Estoicismo e o Cinismo. Nossa pesquisa baseia-se em dados bibliográficos, a partir de análises dos teóricos do Novo Testamento, como: Bart Ehrman e Reza Aslan. Os Historiadores da Igreja Primitiva, como: Paul Johnson e Karen Armstrong. Historiadores do século I d. C, como: Tácito, Flávio Josefo e Suetônio. O livro de Philipp Vandenberg, biógrafo do Imperador Nero. Considerou-se documentários e livros-textos sobre esse assunto e páginas na internet e também contamos com as análises do Novo Testamento.

Palavras-chave: Cristianismo, paleocristão, Jesus histórico.

\section{INTRODUÇÃO}

O texto que é lhe apresentado tem como objetivo separar o Jesus Histórico do Jesus Canônico. Essa tarefa é bastante árdua, até para os especialistas em Novo Testamento. $O$ que será apresentado é a ideia de que no século I d. $C$ havia diversos personagens intitulados "Messias" ou milagreiros. Neste caso, Jesus seria apenas mais um na lista. $O$ fato de Jesus ter mais destaque entre seus concorrentes seria devido às publicações de diversos Evangelhos (canônicos ou apócrifos), mostrando ser ele uma pessoa muito mais presente no mundo mitológico do que humano. Os Evangelhos criaram a ideia de Jesus como alguém sobrenatural. Na verdade, algumas das mensagens que Jesus teria dito foram acrescidas muito tempo depois dos Evangelhos terem sido escritos. Um exemplo disso é a passagem "da mulher pega em adultério" que, por lei, deveria ser apedrejada (João 08: 03-11).

Essa passagem está em todas as bíblias atuais, mas ela foi escrita na Idade Média. O Novo Testamento, sendo, o mais antigo, os códices Sinaítico e Vaticano (datados entre 330-360 d. C) nada dizem sobre essa passagem. O mesmo poderia ter ocorrido com outros "dizeres" atribuídos a Jesus que iremos estudar. É muito difícil separar a pessoa de seu mito, pois é criada por indivíduos que nunca ouviram sua pregação ou teriam visto pessoalmente. Para se ter uma ideia o Evangelho de Marcos foi escrito 
pelo discípulo de Pedro. Lucas era discípulo de Paulo que escreveu: Atos e o Evangelho de Lucas (Lucas e Marcos nunca viram Jesus). O mesmo ocorre com o Evangelho de Mateus (era discípulo der Jesus, mas alguns teólogos atestam o contrário) e com o último Evangelho atribuído a João, que, com certeza, não era um dos 12.

Jesus foi o produto do seu mundo. No século I d. C existiam diversas correntes religiosas judaicas e filosóficas, como, por exemplo, à pertencente aos Cínicos e aos Estoicos. Porém, a influência maior de seu ministério teria sido a dos Essênios. Tanto Jesus como João Batista muito provavelmente teriam se deixado influenciar por essas filosofias. Tendo isso em foco e fundindo-se um pouco as ideias paulinas nasceu o cristianismo de hoje.

\section{COMO ERA ISRAEL NO TEMPO QUE JESUS VIVEU?}

O período que iremos estudar foi marcado pelo principado Júlio-Claudiano: de Augustos a Nero (27 a. C a 68 d. C). Nesta época, Roma controlava a região da Palestina. Ali, o rei Herodes (73-04 a. C) governava a Judeia. Em seu reinado, encomendou diversas obras arquitetônicas, como "O Templo de Jerusalém", "O Porto na cidade de Cesareia" e "A urbanização de Séforis" (uma cidade romana próxima a Nazaré, a $07 \mathrm{~km}$ ). Isso possibilitou o contato dos Judeus com outros povos e influenciou o aparecimento de seitas judaicas e talvez a mais importante fosse a dos Essênios. Segundo a tradição cristã, Jesus teria vindo a Terra para resolver o problema da queda do Homem no Paraíso (Adão) e a introdução do pecado no mundo. O objetivo de Jesus era a remissão dos pecados. O próprio Jesus afirmava que sua vinda seria aos doentes e não aos saudáveis (Mateus 09: 10-13).

A teologia de remissão dos pecados era atribuída a João Batista e é possível que Jesus tivesse sido um de seus seguidores (ERHMAN, 2014). Seu pensamento era muito particular e é possível que esse profeta tivesse tido influência religiosa dos Essênios. É importante frisar que entre o século I a. C e o século I d. C, havia 24 seitas judaicas. Isso quer dizer que o corredor sírio-palestino, nessa época, fervilhava de novos pensamentos, o que favoreceu o surgimento de novas seitas religiosas e 
facções judaicas. As mais importantes eram Zelotes, Fariseus, Essênios (do Mar Morto), os Samaritanos e os Saduceus (JOHNSON, 2001). Na época em que Jesus viveu (25-30 d. C), havia vários filósofos e religiosos que estavam em constante migração e que faziam milagres, como: Apolônio de Tiana, que teve seu nascimento "acompanhado de algo incomum no céu. Adulto saiu de casa para criar seu ministério, curava doentes e ressuscitava os mortos" (EHRMAN, 2014, p. 22).

Os seguidores e outros historiadores afirmavam que Apolônio de Tiana era filho de Deus. O nascimento de Jesus e de Apolônio se deu por forma milagrosa. Entre 10 a 90 d. C vemos que Apolônio e Jesus não eram "os únicos" milagreiros, na região. Havia Simão de Pereia, chamado de "Messias" e ressuscitou ao terceiro dia. Honi, O Desenhador de Círculos, chamado assim devido à uma seca forte que atingiu a Galileia, e, nesse momento, ele desenhou um círculo no chão e disse a "Deus": "Juro por seu grande nome que não vou sair daqui e ficar dentro do círculo até que tenha piedade de seus filhos". Ao terminar de falar começou a chover. Havia o rabino, Hanina Ben Dosa, que também viveu na Galileia e tinha a habilidade de orar para os doentes que ficavam curados após essa prece.

Assim como Jesus, eles viviam na Galileia. Depreendemos que Jesus deveria ter ouvido falar de Hanina e de seu "poder" de cura a partir da oração e isso teria chamado sua atenção, pois, em suas pregações, Jesus falava sobre a importância da oração (Mateus 07: 07-08). Vemos que no Antigo Testamento[2], o sumo-sacerdote era o canal entre o povo e "Deus", usando a oração para isso. Os Evangelhos narram que o povo não sabia orar e Jesus intercedeu. Daí nasceu a oração do "Pai Nosso" (Mateus 06: 05-13). Para Jesus, a oração deveria ser feita por todos ao invés de ser uma exclusividade de poucos. Segundo Ehrman (2014), no mundo do século I d. C as pessoas acreditavam que os deuses greco-romanos e deuses de outros povos poderiam, a qualquer hora, descer à Terra, e, vindos do céu, assumiam formas humanas ou ressuscitavam outras. Isso explica por que o povo confundia Jesus com João Batista falecido, argumentando que ele teria ressuscitado dentre os mortos (Mateus 14: 02). 


\subsection{O PROBLEMA DE ENCONTRAR O JESUS HISTÓRICO}

A História é uma ciência voltada para entender o passado humano. Para isso, requer documentos para analisar os fatos históricos. No caso de investigar o Jesus Histórico teremos de analisar fontes materiais e imateriais para entender o seu mundo. Assim, analisaremos fontes externas ao Novo Testamento, como a Sociologia, Filosofia, Arqueologia Bíblica, História e Psicologia (FUNARI, 2012). Os relatos bíblicos e apócrifos, durante séculos, criaram exageros sobre Jesus, como, por exemplo, o Evangelho apócrifo de Pseudo-Mateus 18 que afirma que:

Três rapazes viajavam com José, e uma jovem com Maria. E eis que de repente saiu da caverna uma multidão de dragões, e quando viram, as crianças gritaram de terror. Então Jesus desceu do colo de sua mãe, se colocou na frente dos dragões e eles o adoraram e se foram. E assim foi cumprida a profecia de Davi, Louvado seja o Senhor na terra, os dragões, vós e todos os abismos[3].

Porém, entre 30 a 65 d. C, o Jesus Histórico não foi mencionado por nenhum: historiador, filósofo, político e religioso ou poeta greco-romano vindo de fontes neutras. Uma pessoa que fazia prodígios reservados aos deuses, como milagres, multiplicação de comidas, curas, morreu e ressuscitou dentre os mortos. Fazendo tudo isso e ninguém ter escrito nada a respeito é estranho. A grande maioria dos cristãos cita que Flávio Josefo (37 a 100 d. C), ao escrever "A História dos Judeus", comentou sobre vida de Jesus. O problema é que Josefo escreveu sua obra 60 anos após a morte de Jesus (ERHMAN, 2014). O seu livro teve acréscimos feitos por Eusébio de Cesárea, no século IV d. C. Suetônio e Tácito não eram contemporâneos de Jesus, mas, em suas obras, há passagens breves sobre Cristo, que foi chamado de: "Crestos" [4] [5].

Suetônio cita que na época do Imperador Cláudio (41-54 d. C): "como os judeus se revoltaram continuamente por instigação de certo Cresto, expulsou-os de Roma" (SUETÔNIO, 2003, p. 206). Há os historiadores contemporâneos de Jesus, como Plínio, o Velho (23-79 d. C), Filo (10 a. C-50 d. C), Petrônio (27-66 d. C), Plutarco (46- 
126 d. C) e Sílio Itálico (25-101 d. C). Contudo, nenhum deles escreveu algum tratado sobre a vida de Jesus. Na verdade, os cristãos apenas compuseram a História devido ao incêndio em Roma em 64 d. C. Dos 14 bairros que existiam apenas 4 ficaram intactos (TÁCITO, Livro XV). De acordo com Tácito, houve um boato entre os romanos que Nero incendiou a cidade:

Nem as medidas de caráter humanitárias, nem os donativos feito pelo imperador, nem as cerimônias expiatórias faziam calar o clamor público de que Nero teria ordenado o Incêndio (VANDENBERG, 1981, p. 176).

O Historiador romano Suetônio, em sua obra "A Vida dos 12 Césares", alegou que os boatos não possuíam espírito crítico e eram maldosos, nascendo, então, a "Hipótese Incendiária". O historiador alemão Philipp Vandenberg observou que Nero fez tudo o que pode para conter o incêndio, e, mesmo assim, a "Hipótese do Nero, O Incendiário" prevaleceu. Muitos perderam suas casas e sua fortuna nesse incêndio. Nero garantiu que os cidadãos fossem restituídos, segundo sua classe social. Em 64-65 d. C a cidade foi reconstruída. Nero urbanizou a cidade abrindo largas avenidas com ângulos retos, com o intuito de evitar propagação de futuros incêndios e foi construída uma nova forma de distribuição de água.

Além do mais, novas construções públicas ou particulares teriam proteção contra incêndio (VANDENBERG, 1981). Nero usou terras particulares e construiu seu castelo: "Domus Aurea" ou a casa dourada (TÁCITO, Livro XV). Isso acarretou o espalhamento do boato, pelos cidadãos romanos, de que o imperador havia posto fogo na cidade pra construir sua casa dourada. E Nero culpou os cristãos (SUETÔNIO, 2003). Pelo incrível que pareça, os romanos não sabiam a diferença entre um judeu e um cristão. Os romanos achavam que se tratava de uma mesma religião. Tanto os judeus e os cristãos eram contrários ao politeísmo e à adoração ao imperador (daí surgem as perseguições).

Os romanos detestavam práticas que envolviam sacríficos humanos e canibalismo (VANDENBERG, 1981). Tácito descreveu os primeiros cristãos como assassinos ritualísticos e canibais (devido à prática da ceia ou eucaristia: tomar o sangue e o 
corpo de Jesus) (TÁCITO, Livro XV). Segundo Vandenberg (1981), Roma no século I d. C tinha um milhão de habitantes, tendo, talvez, mil cristãos. Destes mil, somente $20 \%$ foram perseguidos por Nero. Concluímos que entre o ano de 30 até $65 \mathrm{~d}$. C houve um vazio de documentação sobre a história e vida de Jesus, oriunda de fonte externa.

\section{HISTÓRIA DO CRISTIANISMO ENTRE: 30-65 D. C}

Entre a morte de Estevão, em 35, até a 1ª Epístola de Tessalonicense, escrita em 51, o cristianismo é cercado de obscuridade por falta de documentos. Paulo foi o primeiro escritor cristão. $\mathrm{O}$ que ele sabia sobre Jesus era que: $1^{\circ}$ ele era judeu; $2^{\circ}$ era descendente de Davi; $3^{\circ}$ foi traído e morto e $4^{\circ}$ que ressuscitou. Na verdade, Paulo nunca conheceu Jesus pessoalmente (JOHNSON, 2001). A mensagem de Jesus, do ponto de vista de Paulo, era muito mais atraente para o gentio, pois se afastava de um messias político-militar de Israel e esse líder militar, para os outros povos, não significava nada. O "Messias" que os Judeus esperavam seria um zelote: um líder militar que expulsaria os romanos da Judeia e iria inaugurar um novo reino. Já o "Messias" de Paulo era muito mais atraente para o mundo. No mundo do século I d. $C$ os judeus achavam melhor serem cidadãos romanos do que ser cidadão de um Estado de Israel, que era o caso de Paulo (JOHNSON, 2001).

Ele pregava duas Teologias: 1: a Predestinação e 2ํ: a missão entre os gentios (começou a pregar entre 40-67 d. C). A pregação de Paulo chamou atenção dos discípulos ainda vivos e das testemunhas oculares que conviveram com Jesus, em Jerusalém (especialmente Pedro) (JOHNSON, 2001). É bom frisar, ao leitor, que, nessa época (30-65 d. C), não existiam os Evangelhos. Não existiam Igrejas-Templos (a instituição cristã, como a Igreja Católica), pois surgiram 230 d. C. Não existiam as Teologias Modernas como Pecado Original, Trindade, Arrebatamento, Inferno e Purgatório. Os paleocristões não tinham sacerdotes. Reuniam-se uma vez por semana nas casas dos membros. Oravam juntos, faziam a ceia e leituras eclesiásticas (SUFFERT, 2001). Não havia uma organização central: "o cristianismo começou em meio à confusão, à controvérsia e ao cisma e assim prosseguiu" (JOHNSON, 2001, p. $58)$. 
Johnson (2001) afirmou que houve inúmeras "variedades de cristianismo". As mais importantes eram o Ebionismo[6], composto por judeus-cristãos (as testemunhas oculares que viveram com Jesus e pregavam no Templo de Jerusalém). Havia as ideias de Paulo, o Paulismo e o Gnosticismo[7]. O culto dos Gnósticos era muito desorganizado. Não havia hierarquia sacerdotal, e, por isso, não havia controle clerical. Não tinham uma organização financeira e isso causou a sua extinção no século V (JOHNSON, 2001). Os ensinamentos de Paulo eram completamente diferentes dos ensinamentos dos Ebionistas. Por isso era necessário traçar uma unidade cristã. Daí nasceu o Concílio de Jerusalém, por volta de 49 d. C. Ali ficou definido que: $1^{\circ}$ : Incluir, na nova seita, os gentios; 2o: Afastar-se do judaísmo rabínico; 3: Os gentios convertidos não teriam necessidade de fazer a circuncisão e 4으: Fim de certos rituais judaicos.

Porém, Ebionistas, preferiram não seguir essas determinações (JOHNSON, 2001). Os Ebionistas eram mais adeptos à logística do que Paulo, pois: 1으: tinham autoridade divina (eles conviveram e viram os milagres que Jesus e Paulo nem teve acesso a Jesus); 2: ambos atuavam na mesma área e 3: tinham mais dinheiro, recursos e mais pessoal do que Paulo. Tudo caminhava para uma supremacia Ebionistas, até a eclosão da 1a Guerra romano-judaica (66-73). Esse conflito provocou o desaparecimento da comunidade cristã da Palestina e de Jerusalém. Quando Paulo morreu, em 67 d. C, havia uma aproximação entre os Ebionistas e o judaísmo rabínico. "Quase" que a teologia de Paulo morreria junto com ele (JOHNSON, 2001). Paulismo sobrevive até os dias atuais por causa de dois eventos diferentes e independentes que aconteceram quase que simultaneamente e geraram consequências para os cristãos sobreviventes:

1. O incêndio de Roma, em 64 d. C, provocou a dispersão de cristãos da teologia paulina pelo Império Romano, misturando-se com outras comunidades cristãs, e, assim, era espalhada, enquanto os Ebionistas estavam concentrados na região da Judeia e Galileia.

2. Com a 1 ${ }^{\text {a }}$ Guerra Judaica contra Roma, em 66-73 d. C, teve-se: $1^{\circ}$ : a destruição do Templo de Jerusalém onde se reuniam Ebionistas e judeus e 2o: 0 
desaparecimento de cristãos Ebionistas da Galileia e Judeia a partir de 70 d. C (JOHNSON, 2001).

A 1a Guerra Judaica de 66-73 d. C teve como resultado a destruição do Templo de Jerusalém e destruição das seitas judaicas, como Zelotes e Saduceus. O restante foi escravizado. Morreram 1,5 milhões de pessoas. Isso abriu um vazio teológico paleocristão, sendo preenchido pelo Paulismo (JOHNSON, 2001). A partir de 70 d. C, os sobreviventes começaram a escrever os Evangelhos. $O 1^{\circ}=$ Evangelho é 0 de Marcos. Ele não era apóstolo. Nunca viu Jesus e nunca foi seu discípulo.

Marcos era discípulo de Pedro, que era analfabeto. O $2^{\circ}$ Evangelho era de Mateus escrito pelo "suposto" discípulo de Jesus. $\mathrm{O} 3^{\circ}$ Evangelho era de Lucas, que também escreveu Atos. Lucas era discípulo de Paulo e congregava das mesmas ideias que Paulo. E o Evangelho de João, segundo Funari, "seguiu caminhos próprios" (FUNARI, 2012, p. 9). Raymond E. Brown, autor de: "Uma Introdução ao Novo Testamento", considera que as datações dos quatro Evangelhos são: Marcos: 68-73 d. C. Mateus: 70-100 d. C. Lucas: 80-100 d. C. e João: 90-110 d. C.

\section{PROBLEMAS COM OS EVANGELHOS}

É importante salientar que entre 30-65 d. C, os Ebionistas que viviam na Judeia não tinham objetivo de escrever um Evangelho sobre a vida de Jesus e, também, não tinham a intensão de edificar uma Igreja Cristã (pois o Templo de Jerusalém já era usado). Os paleocristões acreditavam que Jesus retornaria ainda no século I d. C (SUFFERT, 2001). Segundo Paulo, o objetivo de suas missões era alertar o povo acerca do Fim do Mundo e do retorno do Messias (JOHNSON, 2001; EHRMAN, 2014). Com o incêndio em Roma, em 64 d. C, e com a Tomada de Jerusalém pelos romanos em 70 d. C, mudou-se a estratégia dos paleocristões. Antes de $65 \mathrm{~d}$. C havia apenas as epístolas de Paulo, que eram cartas postais para as primeiras comunidades (Romanos, Tessalônica, Corinto e Éfeso) tratando de assuntos diversos e conselhos administrativos, condutas e assuntos religiosos (EHRMAN, 2006). 
A $1^{\text {a }}$ judaica-romana 66-73 d. C causou um impacto muito grande no povo judeu, principalmente nos cristãos. O Templo de Herodes de Jerusalém foi saqueado e destruído. Os cristãos e os judeus estavam cercados em Massada (fortaleza judaica no alto da montanha, em que a população que se refugiou ali, preferiu suicidar-se a se render). Diante desta nova realidade, fica uma pergunta. Como passar a diante a nova seita religiosa fundada pelos seguidores de Jesus? É necessário que os próprios paleocristões escrevessem sobre a pessoa de Cristo. Foi assim que surgiram os Evangelhos (tanto os canônicos como os apócrifos) (EHRMAN, 2014). As comunidades cristãs começaram a fazer um levantamento de dados e recolher informações com as testemunhas oculares que conviveram com Jesus e seus Apóstolos, que estavam morrendo, sem presenciar a segunda vinda do Messias.

Assim, começou-se a reunir todo o material para que os escritores dos Evangelhos pudessem ter o que escrever segundo sua ótica pessoal e seu ponto de vista. Vemos que os Evangelhos de Marcos, Mateus e Lucas tem muita afinidade entre si e se complementam (pelo menos algumas partes). Esses evangelhos são chamados de Sinóticos. A palavra Sinótico é de origem grega e significa "ver junto". O Evangelho de Mateus e Lucas aponta algumas informações de Marcos e de outra fonte usada era o " $Q$ ", do alemão Qelle, que poderia ter sido um documento escrito ao invés de ser uma tradição oral (JOHNSON, 2001). Os Evangelhos citam que Jesus havia profetizado que o Templo de Jerusalém seria destruído[8]. Em Atos e Lucas lê-se que "Deus" não habita em construções feitas pelos homens: "O Deus que fez o mundo e tudo que nele há, sendo Senhor do céu e da terra, não habita em templos feitos por mãos de homens" (Atos 17: 24).

Mas qual é a intensão disso? Ora, para Lucas e Paulo a Igreja-Templo não era necessária, ou seja, ela não tinha autoridade divina (JOHNSON, 2001). Isso foi uma crítica aberta aos judeus rabínicos e aos judeus cristãos. Antes de $65 \mathrm{~d}$. C, os Ebionistas usavam o Templo de Jerusalém para propagar suas ideias, havendo uma aproximação entre os judeus rabínicos e os cristãos judeus, sendo atrapalhada com a guerra com os romanos. Observando as correlações entre os evangelhos sinóticos, percebemos que, em alguns aspectos, eles se complementam, mas existem muitas 
contradições e acréscimos, como, por exemplo, a epístola I João 05: 7-8, Mateus 28 : 19 e o Evangelho de João 7: 53 até João 08: 1-11 e Marcos 16: 09-20. São acréscimos escritos muito tempo após os eventos (JOHNSON, 2001). Os Evangelhos Sinóticos e de João têm inúmeras contradições (EHRMAN, 2014) e, assim, vamos separá-las em três partes para estudá-las:

1. Parte I: natividade e genealogia de Jesus;

2. Parte II: a transformação da água em vinho e as curas (milagres);

3. Parte III: o seu julgamento, suplício e a ressurreição dos mortos (auto sacrifício).

\subsection{1a PARTE: NARRATIVIDADE E GENEALOGIA DE JESUS}

No Mundo Antigo, as estórias de Heróis gregos (Perseu, Hércules e Aquiles) são cercadas da união entre o Céu e a Terra (EHRMAN, 2014). Os deuses unem-se com as mães terrenas. O nascimento de Jesus por meio de Anunciação dos céus, concepção virginal e divina, é semelhante à Gilgamesh[9], na Mesopotâmia, à Vishnu, na Índia e à Apolônio de Tiana, na Grécia (EHRMAN, 2014). De acordo com Suetônio, Júlio César era da família de Anco Márcio e era filho de deuses (EHRMAN, 2014). Buda, Lao-Tsé e Confúcio também eram chamados de filhos de "Deus". Agostino Giogi, no século XVIII, havia registrado:

Quando observei que este povo já possuía um deus baixado do céu, nascido de uma virgem de família real e morto para redimir o gênero humano, minha alma se turvou e permaneci muito confuso. Posso acrescentar que os tibetanos rejeitaram os oferecimentos dos missionários, dizendo: para que vamos nos converter ao cristianismo, se já temos crenças idênticas às vossas e, que, além disso, são muito mais antigas? (GIORGI, 1742, p. 19)

Segundo a lenda Asteca, Quetzalcóatl era barbado e tinha a pele clara. Ensinou o povo a cultivar os campos, construir templos e estabeleceu o comércio. Ele se alto- 
exilou prometendo que um dia voltaria e atravessaria o mar a oeste (onde o sol se põe):

Os Astecas eram politeístas, praticando o sacrifício humano e, em algumas áreas, o canibalismo ritual; porém, havia igualmente pontos de semelhança com o cristianismo - seu deus principal nascera de uma virgem, comiam imagens suas de massa duas vezes por ano, tinham formas de batismo e confissão e uma cruz com os pontos cardeais (JOHNSON, 2001, p. 489).

As semelhanças entre Jesus e os personagens mitológicos e históricos podem ser encontradas, também, na história do Egito por Amenófis III (1402-1364 a. C). O deus Thot veio como mensageiro angelical para anunciar a sua mãe, Mutemuia, que daria a luz à um menino e à sua concepção virginal seria entendida como divina. $\mathrm{O}$ deus Amon, atuando como força criadora, iria engravidar a mãe de Amenófis III, que iria gerá-lo. Segundo a tradição romana, contada por Lívio, Rômulo, fundador da cidade de Roma, era filho de uma virgem vestal (que tinha uma vida de celibato), que foi engravidada por Marte (o deus sol). Ora, de acordo com a cultura da antiguidade era muito comum pessoas extraordinárias terem seu nascimento entre a união do céu (os pais eram os deuses) com a terra (as mães virgens) (EHRMAN, 2014).

Em um dado momento, os escritores do Evangelho, ao fazer cópia das cópias, cometeram um erro intencional. Neste caso, os copistas quiseram transmitir a ideia de que a concepção de Maria foi um milagre. A palavra grega usada aqui foi "Paternos" que significa virgem, ao invés de usar a palavra hebraica "Almah" que significa "jovem moça", como constava nos primeiros escritos. No que se refere à natividade de Jesus, há apenas dois Evangelhos que falam disso que são Lucas e Mateus. Segundo o Evangelho de Mateus, ocorre a chegada dos "magos". Mais tarde, Orígenes irá inventar o título de "reis" que chamamos hoje. Segundo a Lei (Torá), os judeus não deveriam ter contato com magos, adivinhos, espíritas e bruxas (Lv 19: 26. Lv 19: 31. Lv 20: 6. Ex 22: 18 e Dt 18: 10-11). A lei é clara. 
Os judeus estarão cometendo pecado em ter contanto com "magos", incluindo o Messias. Por lógica, José e Maria, junto ao bebê Jesus, cometeram pecado por aceitar presentes de "magos". Por essa razão, a grande maioria dos Teólogos sugere que a viagem dos "reis-magos" é uma invenção do autor do Evangelho. Concluindo, o autor do Evangelho de Mateus queria passar a informação de que Maria engravidou virgem de Jesus, com o objetivo de forçar o cumprimento de uma profecia dita por Isaías ao rei de Acaz uma vitória sobre os Assírios que nada tem a ver com Messias. O Império Assírio deixou de existir em 612 a. C. Os "reis-magos", segundo a tradição cristã, seguiu uma "Estrela". Ela é a "Estrela de Belém". No mundo antigo os cometas, eclipses ou estrelas cadentes eram sinal de mau agouro. Isso representava o aparecimento de guerras, fome e epidemias[10].

O Apocalipse menciona que: "as estrelas caindo na Terra" (Apocalipse 08: 9-11). autor do Evangelho de Mateus, contrariando as crenças populares, descreve a "Estrela" que, para ele, seria um sinal positivo para a humanidade. Porém, em Lucas, Marcos e João nada há sobre a "Estrela", sendo que isso é bastante estranho (Mateus 02: 1-10). Alguns estudiosos sugerem diversas hipóteses, sem provas conclusivas, alegando que a estrela teria sido uma explosão de supernova, alinhamento planetário, cometa Halley etc. Outro evento estranho em Lucas e Mateus foi a viagem para Belém feita pela Família Sagrada. Em Lucas 02: 1-3 alega-se que Quirino, governador da Síria e da Judeia, fez um censo na região e isso obrigou José e Maria irem até Belém.

O censo romano servia para saber a quantidade de cidadãos que existia numa cidade, para, assim, poder cobrar impostos. É nesse contexto que os zelotes surgem, sendo contra o pagamento de impostos para Roma e foram eles que começaram a $1^{\text {a }}$ Guerra Judaica. Ocorre, aqui, um problema de datação. Herodes Antipas, rei dos Judeus, morreu em 04 a. C. O censo de Quirino ocorreu no ano 06 d. C, ou seja, existem 10 anos de diferença de um fato para o outro. Se Jesus realmente nasceu em Belém, de acordo com as informações de Lucas 02: 16-17, na época de Quirino, então toda a cronologia de Mateus deveria estar errada. Ou há probabilidade de a cronologia de Lucas estar errada. É muito provável que a estória da natividade de Lucas e Mateus sejam inventadas. Os impostos eram cobrados, nas cidades, das pessoas que nelas 
moravam. Nesse caso, quem se deslocava eram os censores (responsáveis pelos recenseamento).

Não havia a necessidade de deslocamento das pessoas para outra região para fazer o censo, pois, se assim fosse, seria um desastre logístico. Então por que Lucas insiste na ideia de que Jesus nascesse em Belém? A resposta é para relacionar seu nascimento com a casa real de Davi. Outra informação em Lucas 02: 21-22 tange a sua purificação. Após o parto, existe a lei para as mulheres se limparem. Não há necessidade do homem fazer isso (na Bíblia NVI: “deles"). Lucas sugere que após o nascimento de Jesus, a criança foi apresentada ao Templo, em Jerusalém (Lucas 02: 21-24). Já após o nascimento de Jesus, a família foge para o Egito (Mateus 02: 1323). Aqui não há consenso entre Lucas e Mateus. O Objetivo de Mateus é explicar duas coisas: 1a) a morte de crianças de menos de dois anos, em Belém (o escritor quer comparar Jesus a Moisés) e $2^{\mathrm{a}}$ ) Mateus quer forçar o cumprimento da profecia de Oseias 11: 01[11].

O foco em Oseias 11 é o povo de Israel que estava cativo no Egito. Alega-se que "Deus" tirou o seu povo de lá. Neste caso, Oseias não está falando de um Messias e sim do povo de Israel, chamado de: "Filho de Deus" (EHRMAN, 2014). A ordem de Herodes de matar as crianças também não existiu. Herodes deixou uma farta documentação sobre seu reinado e Flávio Josefo escreveu sobre a História dos Judeus e nela não consta nada sobre o episódio narrado por Mateus 02: 16-18. Por que não? A fuga para o Egito aparece apenas em Mateus. Lucas não faz nenhum comentário sobre esse episódio. A maioria esmagadora dos teóricos sugere que os episódios da natividade: fuga para o Egito, Estrela Cadente, reis-magos, morte de crianças ordenada por Herodes, nada disso aconteceu. Tudo isso seria uma construção simbólica ou uma Hagiografia (biografia de algum santo, em que o autor mistura elementos reais com simbolismos). 
Quadro 1: Elementos bíblicos

ELEMENTOS ÚNICOS EM MATEUS:

1. Estrela-Guia.

2. Os Reis-Magos.

3. Matança das crianças em Belém, por Herodes.

4. Fuga para o Egito.

\section{ELEMENTOS ÚNICOS EM LUCAS:}

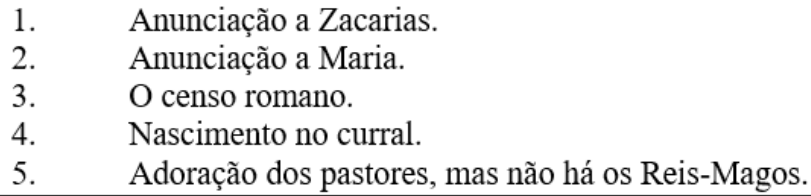

ELEMENTOS COMUNS DA NATIVIDADE:

1. Concepção através do Espírito Santo.

2. Nascimento em Belém.

3. Estabelecimento em Nazaré.

Fonte: Natgeo (2009)

No que se diz respeito ao estudo da Genealogia de Jesus percebemos que apenas Lucas e Mateus se deram o trabalho de fazê-lo. Porém, ambas as genealogias foram realizadas pelo lado paterno, a partir de José. Não existem provas em Lucas ou Mateus de que a genealogia de Jesus teria sido realizada pelo lado materno, neste caso, Maria. Tanto Mateus como Lucas afirmaram que a linha genealógica investigada é por lado paterno. Mesmo assim, há contradições. Por exemplo, Eli gerou José, que gerou Jesus (Lucas 03: 23). E Jacó gerou José, que gerou Jesus (Mateus 01: 16). Em ambos os textos aparece, nitidamente, o nome dos pais de José (Eli ou Jacó). Se a genealogia de Lucas 03 engloba Maria, o próprio texto não diz. Os nomes Salatiel e Zorobabel aparecem tanto no texto de Lucas como em Mateus. Caso a genealogia fosse por parte de mãe (Maria) esses nomes não iriam aparecer.

Essa é uma das provas que os autores dos textos queriam passar uma ideia que Jesus teria uma ascendência da casa real de Davi pelo lado paterno. Até o presente momento, ainda não foi apresentado algo que comprove o lado materno da genealogia de Jesus. A genealogia de Lucas não é do lado materno e sim paterno, quando se lê os descendentes de José. Agora o que dizer de Eli e Jacó serem pais de José? Há uma hipótese que Eli morreu sem filhos e Jacó teve, como esposa, a viúva de Eli e 
que Jacó e a viúva geraram José, pai de Jesus. Não há provas visíveis sobre isso (históricas e arqueológicas). Neste caso, é uma hipótese inverificável (não há como verificar). O que existe, de fato, são apenas conjecturas, suposições e hipóteses sem fundamentos bibliográficos.

Isso demonstra que a genealogia de Jesus é nula e inútil em razão de alguns pontos: $1^{\circ}$ ponto: o pai de Jesus é "Deus", assim sendo Jesus não tem descendência por parte de Davi. Então a genealogia de Jesus é nula e $2^{\circ}$ ponto: se Jesus for descendente de Davi por meio de José, então a genealogia deve ser inútil, pois isso anularia sua concepção por meio do Espírito Santo e Jesus seria humano, sem atributos divinos (uma pessoa comum). Concluindo, os Evangelhos, no que tange a genealogia e a natividade de Jesus, não podem ser considerados fatos históricos (porque não existe nenhuma confirmação factual dos acontecimentos ali narrados). É muito possível que Jesus tivesse nascido de forma comum. Teria sido uma pessoa comum, sem atributos fantásticos. Vemos que a maioria dos relatos nos evangelhos são atribuídos as visões, conceitos e preconceitos dos próprios evangelistas (cada um palpita sobre quem teria sido Jesus e seu ministério) (EHRMAN, 2014).

\subsubsection{2ª PARTE: A TRANSFORMAÇÃO DA ÁGUA EM VINHO E AS CURAS}

Nesta parte, teremos de dividir nossa pesquisa em quatro partes: a $1^{\underline{a}}$ analisa os prodígios e curas atribuídos à Jesus e entende-se que são semelhantes aos deuses greco-romanos. A $2^{\underline{a}}$ explica que algumas ideias de Jesus eram análogas às filosofias greco-romanas (cínica e estoica) e da seita judaica dos essênios. A $3^{\underline{a}}$ diz respeito às pesquisas que envolvem a memória por sugestão pode acontecer erros falhas de memória. E, finalmente, a $4^{a}$ parte prevê que o processo de copiar manuscritos antigos poderia acarretar alguns erros ou mudanças lexicais causadas de propósito pelo copista (EHRMAN, 2006). De acordo com o Evangelho João 02: 1-11, Jesus fez seu $1^{\circ}$ milagre, registrado na Bíblia, à pedido de sua mãe, Maria. Segundo consta, Jesus transformou água em vinho nas bodas de Canaã. Seis talhas com água foram transformadas em vinho. 
Cada talha comportava de 80 a 120 litros. As bodas de Canaã, segundo a tradição católica, ocorrem, anualmente, em 06 de janeiro. Porém, nessa data, comemorava-se o dia de Dionísio, o deus romano da festa e do vinho. Ao ser analisado esse milagre de forma imparcial, notamos que o autor do Evangelho de João queria igualar Jesus aos deuses greco-romanos. Neste caso, a mensagem do Evangelho era que Jesus era uma pessoa prodigiosa. Porém, o curioso desse milagre é que ele já havia sido feito anteriormente, mas por Dionísio, o deus greco-romano. Segundo consta, o deus Dionísio transformava água em vinho nos dias de sua festa (06 de janeiro). Segundo o teólogo alemão, Rudolf Bultmann (1884-1976) sugere que a Bodas de Canaã foi baseada numa lenda pagã antiga e incorporada à Jesus[12]. O estranho do episódio das bodas é que ele aparece apenas no Evangelho de João.

Não existem menções desse "milagre" nos Evangelhos Sinóticos. Grande parte dos teólogos considera esse episódio como uma lenda. No que diz respeito aos milagres e às curas prodigiosas atribuídas à Jesus, na verdade, eram curas realizadas por outros deuses da antiguidade clássica. De acordo com a mitologia grega, Asclépio (em romano Esculápio) era filho do deus Apolo. Asclépio é o deus da Medicina na Grécia Antiga. Há diversas versões de suas estórias, e, numa delas, Asclépio ressuscitou os mortos. Depois curou aos enfermos usando sua "boa mão". Asclépio curava os cegos com cuspe e barro, igual a Jesus. É muito possível que as curas de Asclépio tivessem influenciado os escritores dos Evangelhos, pois suas estórias são muito parecidas. É possível que isso tenha acontecido por que os Evangelhos foram escritos pelos menos 40 anos após os eventos (morte e ressurreição de Cristo).

E é muito improvável que os Apóstolos tenham escrito, pois depreende-se que a grande maioria era analfabeta ou viveram até uma idade avançada para poder lembrar e dar seu testemunho (em estudos recentes mostra que nossa memória pode pregar peças na gente e fazer inventar estórias falsas). Sobre as bases da filosofia cristã, podemos dizer que ela nasceu a partir do século IV a. C na Grécia Antiga. Ali havia um hábito de transformar seres humanos em deuses devido às qualidades que essas pessoas adquiram ao longo da vida. No século I a. C, iniciou-se o culto aos 
imperadores romanos a partir de Augustos e o imperador só se tornava deus após sua morte e por votação do Senado Romano (SPQR).

Foi a partir do século IV e III a. C que se deu início à duas correntes filosóficas: a filosofia cínica e a estoica. A filosofia cínica é chamada assim porque seus filósofos viviam como os cães de rua (em grego kynikos). Esses filósofos vivam ao relento e se alimentavam quando alguém dava comida a eles. O próprio Jesus afirmou que: "O Filho do Homem não tem onde repousar a cabeça" (Mateus 08: 20). Ou, ainda, tinhase como objetivo receber o Reino dos Céus, e, assim, Jesus sugeriu ao jovem: "Se queres ser perfeito, vai, vende tudo o que tens e dá-o aos pobres, e terás um tesouro no céu; e vem, e segue-me" (Mateus 19: 20-22). Essas passagens apontam o estilo de vida dos cínicos:

Quadro 2: Filosofias

\section{FILOSOFIA CÍNICA}

1) O objetivo da vida é alcançar a felicidade e a virtude, libertando-se da ignorância.

2) A Virtude só é alcançada quando se vive de acordo com a natureza (mundo natural).

3) Deve-se desprender-se do dinheiro e de bens materiais com o objetivo de viver de forma simples. Os cínicos eram alimentados quando alguém dava comida a eles. O Cínico, Diógenes de Sinope vivia dentro de um barril de barro, sem sandálias, sem roupas e cercado de cães de rua.

4) Para os cínicos a sabedoria era baseada nas ações (viver da prática) que temos na Terra e não sendo uma forma de pensar.

Fonte: Autor (2020)

A virtude, para os cínicos, seria uma qualidade basicamente humana que o faz praticar o bem e hábitos que não prejudicam outras pessoas. A virtude é fazer o bem sem uma promessa ou recompensa. Esse tipo de pensamento filosófico se assemelha muito com os pensamentos dos primeiros cristãos, sendo esses judeus ou gentios. 


\section{FILOSOFIA ESTOICA}

1) Para os estoicos as emoções destrutivas (ambição e crimes de qualquer natureza) são destrutivas e deve ser evitados. Para os estoicos o objetivo é controlar os desejos mundanos, controlar os desejos da carne (evitar beber, fazer sexo, jogar).

2) O correto é fazer uma escolha de acordo com a natureza benigna que não interfira na vida do outro. Assim essa escolha não pode destruir o outro.

3) Ser fiel a escolha feita - neste caso ser ético. E procurar ser virtuoso.

Fonte: Autor (2020)

\section{FILOSOFIA DOS ESSÊNIOS}

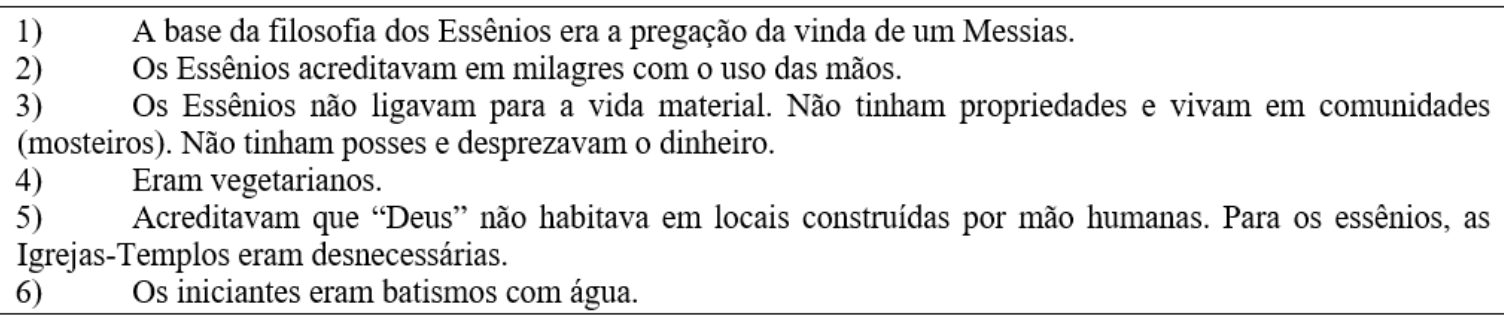

Fonte: Autor (2020)

No que diz respeito ao estudo da memória, segundo as pesquisas coordenadas pela professora Elizabeth Loftus, da Universidade da Califórnia Irvine, especialista no estudo de falsas memória, percebe-se que elas se manifestam quando uma pessoa sugestiona a outra um fato. Esse processo ocasionar um erro na memória e o cérebro pode criar, a partir daí, uma memória falsa. Para a pessoa criar uma falsa memória precisaria de voluntários e esses seriam entrevistados. Nestas entrevistas, há a presença da informação, pressão de autoridade (uma pessoa íntima do voluntário: amigos ou parentes) e de repetição (para sugerir um evento não existente) para que o cérebro do voluntário possa criar uma memória falsa. Mas o que isso tem a ver com os Evangelhos?

Ora, tem tudo a ver. É muito possível que por sugestão e repetição, os apóstolos, a maior parte iletrado e analfabeto, adquiriram, ao longo do tempo, uma falsa memória a respeito de Jesus. Podendo ter até criado distorções que foram parar nos Evangelhos, tanto nos canônicos quanto nos apócrifos. Isso também explica que Jesus havia feito os mesmos tipos de milagres e curas que foram atribuídos aos deuses greco-romanos e orientais e o fato dos textos bíblicos serem diferentes entre 
si. No mundo antigo não existia impressora, xérox e nem mimeógrafo. Todos os documentos oficiais eram redigidos a mão. E, é claro, havia a necessidade de copiar tudo aquilo que já estava escrito - para copiar um manuscrito bíblico antigo levava-se de um a dois anos.

Era um processo muito demorado e muito custoso. No século I d. C os textos sagrados eram escritos em papiro (de fácil deterioração). Por isso necessitava de fazer cópias das cópias. Nos séculos III e IV d. C foi usado o códex (livro). Ehrman (2006) alude que esses textos não tinham pontuação. Não havia espaço entre as palavras. Não havia distinção entre uma letra maiúscula e minúscula. Era copiado tudo junto. Esse tipo de texto era chamado de Scriptuo Continua e poderia confundir ou até criar uma dupla interpretação. Uma letra fora do lugar pode causar interpretações variadas. A maioria dos copistas do século I d. C não eram profissionais. Ehrman (2006) sugere que os textos religiosos foram feitos por copistas inexperientes que erravam, faziam omissões, acréscimos, uso de palavras mal redigidas. Assim, no século III d. C, Orígenes se queixou das cópias dos Evangelhos canônicos alegando que eram mal feitas e mal produzidas (ERHMAN , 2006 ).

\subsubsection{3ª PARTE: JULGAMENTO, SUPLÍCIO E A RESSURREIÇÃO DOS MORTOS}

O teólogo alemão Constantin von Tischendorf descobriu o códex Sinaítico (bíblia antiga), escrito em grego e datado do século IV (330-360 d. C). Assim, resolveu leválo a Europa para estudá-lo e compará-lo com os textos atuais. Tischendorf percebeu que havia muitas discrepâncias, entre elas a relação do Códex Sinaítico com as bíblias modernas que sugere que as edições modernas de hoje em dia têm sido alteradas em muitos lugares e não serão aceitas como verdadeiras. Como um exemplo atual de tradução e alteração do conteúdo bíblico podemos citar a Bíblia das Testemunhas de Jeová, que tem conteúdo diferente, quando comparada com a Bíblia King James, que, por sua vez, tem um conteúdo diferente da Peshitta (bíblia siríaca) ou de outras denominações, como, por exemplo, NVI (Nova Versão Internacional), ARA (Almeida Revista e Atualizada) e ACF (Almeida Corrigida Fiel). É possível que os escribas e 
copistas, ao longo de dois mil anos, tenham feito acréscimos e interpolações de versículos bíblicos já citados anteriormente.

Por isso, muitos teólogos alegam que algumas informações e detalhes bíblicos não batem com informações vindas de textos mais antigos. As bíblias de hoje em dia diferem seu conteúdo das bíblias do século IV d. C (Códex Sinaítico e Vaticano). Isso explica os acréscimos introduzidos muitos anos após a morte de Jesus (durante a Idade Média), e, por essa razão, algumas partes não podem ser confiáveis e não podem ser considerados fatos históricos. A análise dos atuais relatos bíblicos que iremos estudar foi dividida em três partes: 1ํ: o julgamento; 2응 o suplício e $3^{\circ}$ : a ressurreição de Jesus. Ao estudarmos cada um desses tópicos podemos notar que ao mesmo tempo em que se complementam ocorrem às contradições nos depoimentos e a formação de ideológica do autor tende a separar o judaísmo rabínico do paleo cristianismo.

\subsubsection{O JULGAMENTO DE JESUS}

Quando abordamos o Julgamento de Jesus nos Evangelhos notamos que um texto completa o outro, ou seja, concordam entre si. Mas há, também, casos de discrepâncias e contradições. Em Marcos 14 há concordância sugerindo que: Jesus foi preso e levado a casa Caifás. Lá havia: "os principais sacerdotes, os anciãos e os escribas" (v 53). Em Mateus 26 também cita-se o ocorrido: "os principais sacerdotes, os anciãos e os escribas estavam na casa de Caifá (v: 57)". Em Mateus 26 "uma grande multidão" (v: 47) de guardas do Templo ou do sumo-sacerdote foram até o Getsêmani para prender Jesus. Vale a pena salientar que tanto em Marcos como em Mateus sugere-se que a captura de Jesus se deu do mesmo modo. Havia uma multidão armada com espadas e varapaus para prender Jesus (Marcos 14: 43 e Mateus 26: 47).

No mesmo relato, em Marcos e Mateus, sugere-se que "alguém que estava com Jesus" golpeou um soldado do Templo na orelha e Jesus faz sua última cura colocando a orelha do soldado no lugar (Marcos 14: 47 e Mateus 26: 51). Em Lucas 22:50 afirma-se que "alguém que estava com Jesus" golpeou um servo do templo. 
Nos evangelhos sinóticos não há o nome de quem golpeou e de quem foi golpeado, pois essa nomeação aparece no Evangelho de João. Em João 28:10 comenta-se que foi Pedro um dos Apóstolos que estava armado e feriu Malco, o servo do sumosacerdote (ou seja, não era um soldado romano e nem um guarda do templo e sim um escravo). Em Marcos 14 havia muitas testemunhas contra Jesus, mas seus depoimentos eram contraditórios e, por fim, não poderiam ser usados no Julgamento do Sinédrio (v. 56 a 59).

Já em Mateus 26 afirma-se que havia duas testemunhas para falar contra Jesus (v. 60 a 61). $O$ intrigante dos depoimentos que estava entre as testemunhas de Marcos e Mateus fazia a mesma denúncia: "Que Jesus podia destruir o Santuário de Deus e reconstruí-lo em três dias" (Marcos 14:58-59 e Mateus 26:61). Tanto em Marcos como em Mateus é muito provável que o primeiro julgamento do Sinédrio contra Jesus aconteceu na presença do sumo-sacerdote Caifás e ocorreu à noite, pois tanto em Marcos 15:01 como em Mateus 27:01-02, afirma-se que Jesus foi levado à Pilatos pela manhã. Em Marcos 14:17 e Mateus 27:20 sugere-se que antes de ser preso, Jesus passou à tarde com os doze e bem depois foi ao Getsêmani (provavelmente à noite). Com base nesta informação, Jesus foi preso e julgado à noite ou durante a madrugada.

No Evangelho de Lucas 22:66 afirma-se que o sinédrio reuniu-se para julgar Jesus pela manhã. João 18: 28 afirma que Jesus foi levado à Pilatos (Pretório) pela manhã. Então temos em Marcos e Mateus a sugestão de que o julgamento de Jesus foi à noite. E Lucas e João sugerem que todo julgamento ocorreu pela manhã. Segundo Lucas 22, Jesus passou a noite toda apanhando dos oficiais e soldados do templo (v. 63). Em João 18, Jesus não foi maltratado pelos soldados, como aconteceu em Marcos, Mateus e Lucas (atingido por socos, chutes e pontapés). Em João 18, Jesus levou apenas uma bofetada ao responder uma pergunta do sumo-sacerdote (v. 22). Em Marcos e Mateus afirma-se que Jesus foi julgado duas vezes. Uma pelos sacerdotes judeus (Caifás) e outra por Pilatos, governador da Judéia. Porém, em Lucas 22:66 e Lucas 23:01-07 Jesus passou por três julgamentos: o primeiro pela "assembleia dos anciões", presidida por Caifás. 
O segundo julgamento foi feito por Pilatos e o terceiro por Herodes Antipas. Algo parecido ocorre no Evangelho de João. Em João 28:19-24 Jesus foi levado a Anás, onde houve seu primeiro julgamento. E depois Anás pediu para que os guardas levassem Jesus para Caifás para fazer um segundo julgamento. $O$ terceiro julgamento é feito por Pilatos que deu a sentença de morte pela cruz (João 28:28-40). No que diz respeito ao julgamento feito por Pôncio Pilatos, governador romano da Judeia que julgou Jesus à pedido do Sinédrio, Pilatos pergunta à Jesus se ele era o rei dos Judeus (Marcos 15:02 e Mateus 27:11). Jesus respondeu a Pilatos: "Tu o dizes". O julgamento feito por Pilatos, observado em Marcos e Mateus, é muito semelhantes. Aqui, notamos que Pilatos (um representante dos romanos) se retira da situação de Jesus ou lava as mãos.

Quando são analisados os Evangelhos um a um, observamos que seus autores culpam os judeus pela morte de Jesus na cruz. Por exemplo, em Marcos 15:11 sugerese que os sacerdotes instigaram a "multidão". Em Mateus 27:20 também é sugerido que os sacerdotes instigaram a "multidão". Com isso, afere-se que Mateus e Marcos são muito parecidos. Em Lucas 23:18 afirma-se que "todos" pediram a condenação de Jesus e para soltar Barrabás. Em João 19:12 era toda uma "nação" que pedia pela morte de Jesus. No que se refere à Barrabás, provavelmente era um criminoso. Porém, não sabemos nada sobre sua vida.

Os Evangelhos citam que ele cometeu latrocínio e sedição (revolta) e, por isso, foi preso. Alguns teólogos acreditam, por sua vez, que ele teria sido um zelote, mas não dá pra saber. O que sabemos é que a "multidão" escolheu Barrabás para ser solto. Encontramos essas referências nos Evangelhos sobre Barrabás ser liberto nos quatro evangelhos (Marcos 15:07; Mateus 27:17; Lucas 23:18 e João 18-40). Ao mesmo tempo, notamos que a forma como se deu o julgamento de Jesus, baseando-se nos Evangelhos, foi muito atribulado e contraditório entre si.

\subsubsection{O SUPLÍ́cIO}

Em Marcos 15:19-22 comenta-se que Jesus foi levado ao suplício. O que é suplício? Na Bíblia, é a tortura psicológica e física de Jesus. Nesta parte do texto vamos analisar 
o que diz os Evangelhos sobre a chamada Via Crucis ou Caminho da Cruz. Esse caminho é o percurso entre o palácio de Pilatos (Pretório) até o Gólgota (lugar da Caveira). O texto de Marcos sobre esse episódio é seco e muito curto. Segundo Marcos, os soldados romanos levaram Jesus ao pátio do palácio, bateram, cuspiram e xingaram de Jesus (v. 19). Depois o despiram, deixando quase nu (v. 20). No percurso, Simão de Cirene que, segundo o texto "vinha do campo", ajudou Jesus a carregar a cruz, por conta própria, pois Jesus não tinha condições para isso.

A tortura física de Jesus ocorreu desde o palácio até o local de sua crucificação. Marcos fala que Simão de Cirene era pai de Alexandre e Rufo, não dando muitos detalhes sobre quem ele era. O Suplício de Jesus em Mateus 27: 27-32 é mais longo e muito parecido com Marcos, e, é claro, tem suas diferenças. Nesse texto, cita-se que os soldados romanos (do governador) bateram, xingaram e cuspiram em Jesus. Esses soldados fizeram um manto de cor púrpura (carmesim) e vestiram-no. Cita-se, também, a famosa coroa de espinhos que os soldados romanos fizeram e colocaram em Jesus. No que diz respeito ao caminho que Jesus percorreu do palácio de Pilatos até o Gólgota, vendo que Jesus não dava conta de carregar sua cruz, os soldados "obrigaram" (v. 32) um homem chamado Simão Cirineu a carregar a cruz de Jesus.

No texto de Lucas 23:26-31, percebemos que essa parte é bem incomum, pois não é comentado que Jesus teria sido torturado pelos soldados romanos, como vimos em Marcos e Mateus. O texto inicia com Simão aparecendo "vindo do campo" e que puseram a cruz sobre ele, que pôs a levá-la (parecendo ter sido obrigado a fazê-lo). A inovação do texto de Lucas cita que uma multidão e um bando de mulheres (talvez suas seguidoras ou membros de sua família) estavam indo atrás de Jesus na Via Crucis, num cortejo "fúnebre e pranteavam e lamentavam (v. 27). Mas, de repente, Jesus dá uma espécie de sermão, dizendo: "Filhas de Jerusalém, não choreis por mim" (v. 28). É muito improvável que isso teria sido dito, pois as condições físicas de Jesus não permitia fazê-lo, pois havia sido humilhado e torturado das piores formas possíveis e imagináveis, como vimos em Marcos e Mateus.

Já em João 19:01-05 as descrições são muito semelhantes às de Marcos e Mateus. Percebemos que os soldados romanos fizeram a famosa coroa de espinho (mas isso 
aconteceu durante o julgamento de Jesus e não foi em seu suplício). No Evangelho de Lucas não há menção à coroa. Ao mesmo tempo, o suplício de Jesus descrito no Evangelho de João é muito curto, lembrando o de Marcos. Em João 19:16 cita-se que Pilatos entregou Jesus para ser crucificado e isso se deu imediatamente. João sugere que Jesus carregou a cruz sozinho (v. 17). Vemos que os Evangelhos sobre o suplício de Jesus na sua Via Crucis tem versões conflitantes, ora temos coroa de espinhos, ora não temos. Ora temos pessoas ajudando Jesus a carregar a sua cruz, ora não temos. Ora temos discursos ou uma procissão "fúnebre", ora não. Em algumas partes aparecem versões inéditas e diferentes quando comparadas aos demais Evangelhos.

Mas, em compensação, temos a brutalidade dos soldados romanos com a pessoa de Jesus sendo descrita (Marcos, Mateus e João). Terminada a Via Crucis, dá-se início à crucificação de Jesus. Vemos que os Evangelhos mais uma vez se contradiz. Em Marcos 15: 22-47 tem-se um texto longo sobre a crucificação. Segundo Marcos, Jesus foi crucificado na $3^{\underline{a}}$ hora (v.25). E ai vem à parte mais interessante da história da crucificação. Segundo os Evangelhos, foram crucificados, junto com Jesus, dois ladrões, um na sua direita e a outro na sua esquerda (v. 27). Em Marcos, Mateus e João cita-se que os ladrões que foram crucificados junto com Jesus falavam zombavam de Jesus e não se arrependem de sua condição. Em Marcos 15:32, diz-se que: "também os que foram crucificados com ele, dirigiam-Ihe impropérios".

Em Mateus 27:44, o texto sobre os ladrões crucificados com Jesus é semelhante ao de Marcos: "também os salteadores que foram crucificados com ele, dirigiram-Ihe os mesmos impropérios". Em João 19:18, fala-se que foram crucificados dois ladrões juntos à Jesus, um de cada lado. Porém, o texto não diz se esses ladrões zombaram de Jesus. Agora a parte mais interessante. Em Lucas 23:32-42 relata-se que havia muita gente no local da crucificação e que "autoridades" e soldados zombavam de Jesus e que foram crucificados, junto à Jesus, dois ladrões. Um deles se arrependeu de seus pecados terrenos, enquanto o outro zombava de Jesus (v. 42). Esse trecho é único em todo o Novo Testamento. Aparece apenas em Lucas. O motivo disso seria a propagação da Teologia de Paulo, pois Lucas era seu discípulo. 


\subsubsection{MORTE E RESSURREIÇÃO}

Nesta parte do texto iremos comparar os quatro Evangelhos que sustentam os meandros da morte pela cruz e a ressurreição de Jesus. Fora dos Evangelhos, entre o século I a. C e o século I d. C, temos Simão de Pereia, a única pessoa contemporânea à Jesus a ser chamada de Messias e que morreu e ressuscitou dentre os mortos ao $3^{\circ}$ dia. Mas, voltando ao tema, sobre a morte de Jesus, sabe-se que ela se inicia com a via crucis e se finda com a chegada ao Gólgota, processo citado por Mateus, Marcos, Lucas e João, sendo a Gólgota o local de crucificação de Jesus. Segundo o Evangelho de Marcos 15, sugere-se que Jesus teve suas vestes "tiradas" pelos soldados que jogaram a sorte para ficar com ela (v. 24). Esse versículo também está presente em Mateus 27. Ele aponta que, de fato, há um jogo de sorte com o objetivo de ficar com as vestes de Jesus (v. 35) antes de ser crucificado.

Já em João, os soldados se reúnem depois de crucificarem Jesus para jogar a sorte de suas roupas (João 19:23). Em Marcos, Mateus e Lucas afirma-se que as pessoas presentes no local (ou que estavam observando a crucificação) falavam impropérios e ofendiam a pessoa de Jesus (Mateus 27:39, Marcos 15:29 e Lucas 33:35). No Evangelho de João não se cita as zombarias e impropérios. Nos Quatros Evangelhos comenta-se que foi oferecido vinagre para dar de beber a Jesus quando estava pregado na cruz (Marcos 15: 36, Mateus 27:48, Lucas 33:36 e João 19:29). momento da morte de Jesus, segundo os Evangelhos de Marcos e Mateus, teria sido na $9^{\mathrm{a}}$ hora e suas últimas palavras foram: "Eloí, Eloí, lamá sabactâni” (Marcos 15:34 e Mateus 27:46).

As pessoas que estavam vendo a crucificação imaginaram que Jesus teria chamado por Elias (Marcos 15:35 e Mateus 27:47). No Calvário, os Evangelhos de Lucas e João nada comentaram à respeito de Elias. Antes de Jesus vir a falecer, de acordo com os Evangelhos Sinóticos, havia trevas, mas no Evangelho de João não se comentou nada à respeito disso. Após a morte de Jesus, José de Arimatéia reclama o seu corpo para sepultá-lo de acordo com a lei do Torá (Marcos 15:43, Mateus 27:57, Lucas 33:50-51 e João 19:38-39). Mas quem é José de Arimatéia? 
Existem numerosos motivos pra se duvidar da tradição do sepultamento de Jesus por José. Primeiro, é difícil atribuir sentido histórico a essa tradição apenas no contexto da narrativa de Mateus. A identificação de José como um membro respeitado do sinédrio deve levantar questões imediatamente. Marcos disse que no julgamento de Jesus, ocorrido na noite anterior "todo conselho" do sinédrio participou (EHRMAN, 2014, pp. 206-207).

José de Arimatéia ainda é um mistério para a Teologia. Mas, voltando ao texto, os elementos de Marcos sobre o julgamento e a narrativa do sepultamento vêm de diferentes tradições culturais da época que Marcos escreveu seu texto, ou seja, a partir do ano 80 d. C (EHRMAN, 2014). Sobre a morte de Jesus, os Evangelhos citam que o centurião romano percebeu que Jesus era "Filho de Deus", estando essa afirmação em Marcos 15:39 e Mateus 27:54. Já em Lucas 23, sugere-se que Jesus era um: "Homem Justo" (v. 47). Existe, aqui, uma diferença enorme entre ser "justo" e ser "Filho de Deus". Nesse caso, o homem justo não precisa ser, necessariamente, um "Messias". Já ser "Filho de Deus" é algo mais próximo à divindade do ser comparado ao "Homem Justo" (EHRMAN, 2014). No caso do centurião, o objetivo dos autores que escreveram os Evangelhos de Marcos e Mateus era tentar separar a seita cristã do judaísmo tradicional e mostrar, aos romanos, a pessoa de Jesus como alguém extremamente importante.

No exato momento da morte de Jesus, os Evangelhos Marcos, Mateus e Lucas citam que: "o véu do santuário" que ficava dentro do Templo de Jerusalém rasgou-se sozinho, de cima para baixo. No Evangelho de João não há menção ao "véu". Mas, o Evangelho de Mateus é muito fantasioso, pois sugere que: "o véu rasgou-se e houve um tremor de terra" (27: 51). Afirma, ainda, que os mortos ressuscitaram e entraram na cidade de Jerusalém (27: 52). Esse versículo só aparece em Mateus. Marcos e Lucas não comentaram nada sobre isso. Assim, conclui-se que isso não tenha acontecido, porque os romanos não deixaram nenhum relato sobre o terremoto e a ressurreição dos mortos descritos no final do Evangelho de Mateus. O objetivo dos Evangelhos era de criar uma mensagem, substituindo a antiga religião judaica. 
Se o véu do Templo rasgou-se sozinho ou não, a intensão dos autores era dizer que, com a morte de Jesus, "Deus" rompeu seu pacto com o povo Judeu. E, a partir de agora, os judeus não eram mais considerados um povo eleito, de "Deus". É muito provável que houvesse uma placa indicando o motivo da crucificação, assim, quando Jesus foi crucificado, foi colocada uma placa com a inscrição: "O Rei Dos Judeus" (Marcos 15:26) e, ainda: "Este É Jesus O Rei Dos Judeus" (Mateus 27:37); “Este É O Rei Dos Judeus” (Lucas 33:38), e, por fim: “Jesus O Nazareno, Rei Dos Judeus” (João 19:19).

Em João, propõe-se que Pilatos escreveu uma placa em hebraico, latim e grego. Isso só aparece no Evangelho de João. $O$ fato da placa estar escrita em três idiomas não apareceu nos Evangelhos Sinóticos. Então, por que Pilatos ia se der ao trabalho de escrever em três línguas a inscrição da placa? Provavelmente, isso não deveria ter acontecido. É mais provável supor que Jesus morreu com uma placa acima de sua cabeça escrita no idioma latim (a maioria do povo judeu era analfabeta e desconhecia o latim). O Evangelho de João é o único que afirma a ocorrência certos prodígios ou cumprimento de profecias:

1. As pernas de Jesus não foram quebradas com o objetivo de cumprir uma determinada Escritura que afirma que diz que: "nenhum osso será quebrado" (João 19:31).

2. Um dos soldados the abriu o lado com uma lança e logo saiu sangue e água (João 19:31) para cumprir outra passagem nas Escrituras.

Os Quatro Evangelhos sugerem diversos acompanhantes de Jesus em sua crucificação. Em Marcos 15 sugere-se que eram Maria Madalena, Maria, mãe de Tiago, o menor, José e Salomé (v. 40). Em Mateus 27 estavam ali "muitas mulheres", cujas principais eram Maria Madalena, Maria, mãe de Tiago e de José e a mulher de Zebedeu (v. 55-56). Em Lucas 33 afirma-se que estava acompanhado de mulheres que tinham vindo da Galileia com ele (v. 55). João 19 comenta que quem estava perto da cruz de Jesus eram a irmã de sua mãe, Maria, mulher de Cléopas, e Maria Madalena (v. 25). Segundo os Evangelhos Sinóticos, as mulheres estavam 
acompanhando a crucificação ao longe (Marcos 15:40 e Mateus 27:55 e Lucas 23: 49).

Em João, as mulheres já se encontravam próximas da cruz, perto de Jesus (João 19:25). No Evangelho de Marcos é sugerido que Jesus teria sido crucificado a partir da $3^{\mathrm{a}}$ hora (Marcos 15:25), enquanto no Evangelho de João o autor sugere que a crucificação teria ocorrido por volta da $6^{\underline{a}}$ hora (João 19:14-16). Como se sabe, o dia tem 24 horas. Os romanos calculavam o dia em duas partes de 12 horas. Segundo o cálculo da duração do dia para os romanos, quando falamos que Jesus foi crucificado na $3^{\underline{a}}$ hora é o equivalente a 9:00 horas da manhã e a $6^{\underline{a}}$ hora equivale ao meio-dia.

\subsubsection{A RESSURREIÇÃO E A IDEIA DE SACRIFÍCIO}

Essa parte é a mais complexa do texto pelo seguinte motivo: a ressurreição de Jesus é baseada, unicamente, na fé, na crença de que daquilo aconteceu. Os cristãos não têm meios de confirmar, por meio da ciência, se a ressurreição aconteceu. Para complicar, outras culturas e mitologias têm seus heróis cometendo auto sacrífico pela humanidade, como Buda ou Tamuz, na Mesopotâmia. Resumindo, Jesus é apenas mais um entre tantos que se sacrificaram de forma semelhante, é, então, algo típico de heróis mitológicos.

Contudo a ideia da morte sacrificial de Cristo era semelhante ao ideal de bodhisattva, que se desenvolvia na mesma época, na Índia. Cristo se tornava mediador entre a humanidade e o Absoluto, como o bodhisattva, mas era o único mediador (ARMSTORNG, 2008, p. 124).

No que tange a ressurreição de Jesus, a nossa única fonte documental são os Quatro Evangelhos, e, mesmo assim, há contradições. Cada um fala uma coisa diferente do outro. Segundo Marcos 16:02 foi pela manhã bem cedo, quando o sol nasceu, que Maria Madalena foi a Tumba de Jesus. Já em João 20:01 cita-se que era à noite. Outra contradição foi a quantidade de pessoas que foram à tumba de Jesus e o que aconteceu quando essas pessoas chegaram lá. Segundo João 20:01 Maria Madalena estava indo sozinha visitar a tumba (uma pessoa). Em Marcos 16:01 Maria Madalena 
foi com a mãe de Tiago, Maria e Salomé (três pessoas). Em Mateus 28:01 Maria Madalena e outra Maria (não especificada) foram a Tumba de Jesus (duas pessoas). E, finalmente, uma "multidão" de mulheres foi visitar a tumba de Jesus, de acordo com Lucas 24:10, que afirma que Maria Madalena, Joana, Maria, mãe de Tiago, e outras mulheres (que não especificou) foram ao local (várias pessoas).

O ponto em comum nas narrativas é que só havia mulheres. Em todas as citações aparece no nome de Maria Madalena. O que é bem estranho é que os evangelistas não sabem dizer a quantidade das pessoas que foram à tumba de Jesus junto com Maria Madalena. À medida em que há aprofundamentos nos textos, mais contraditórios ficam. A pedra que lacrava a tumba do sepulcro havia sido removida por um anjo que desceu do céu no momento da chegada de Maria Madalena à tumba (Mateus 28:02). Em outra passagem (Marcos 16:02-04) "A pedra já havia sido removida". Porém, Marcos, em nenhum momento, cita que "anjos" estavam na tumba ou até que houve algum tipo de terremoto, citado por Mateus. O próprio Mateus 28:04 narrou que havia guardas (soldados) vigiando o sepulcro de Jesus para impedir que alguém roubasse o corpo dele.

Porém, não existe nenhuma referência disso nos textos de Marcos, Lucas e João. As mulheres, ao chegarem à Tumba, segundo Marcos, viram um jovem. Mateus fala que era um anjo, Lucas fala que eram dois homens e João fala que eram dois anjos. Bem, qual a diferença entre um homem e um anjo? Os Quatro Evangelhos não têm critérios para definir o que é um ser humano de algo angelical. Os seres angelicais, os homens ou o jovem moço estavam dentro da tumba ou fora? Segundo Mateus 28:02, o anjo estava fora da tumba. Já Marcos, Lucas e João afirmam que havia alguém dentro da tumba. Com base nos textos, notamos que cada evangelho possui sua versão pessoal da vida, do ensinamento, da morte e da ressurreição de Cristo.

\section{CONSIDERAÇÕES FINAIS}

Vimos, ao longo do texto, a difícil tarefa de explicar a cultura, o modus vivendis e os povos que viveram no Levante. Mesmo usando os Evangelhos e outras fontes históricas, ainda é muito difícil confirmar a veracidade sobre a vida e morte de Jesus. 
Podemos supor que seus ensinamentos teriam sido influenciados pela cultura religiosa dos essênios, cínicos e estoicos. A pessoa de Jesus apresentada nos Evangelhos é muito complexa e mistura elementos místicos de outros povos e culturas. Por outro lado, não sabemos como se deu seu nascimento, pois o mesmo é cercado de mitos.

Mesmo que Jesus fosse alguém poderoso ou um filósofo judeu com estilo cínico e essênio ainda é carregado pela falta de instrução e pela difusão de seitas judaicas menores que, de algum modo, influenciaram suas pregações e as mensagens que dizia. Nesse texto, procurou-se, ao longo dos capítulos, separados por fases, afastar o Jesus bíblico do Jesus histórico e, infelizmente, o que prevaleceu foi o Jesus mítico. Talvez no futuro, numa escavação arqueológica ou numa descoberta feita por acaso, venha-se acrescentar mais fatos acerca dos mitos na estória de Jesus.

\section{REFERÊNCIAS}

ANDRADE, A. L. Pinheiro de. História da Pesquisa sobre o Jesus Histórico. João Pessoa-UFPB. Revista Religare, v. 11, n. 1, p. 52-66, mar. 2014.

ARMSTRONG, K. Uma História de Deus. In: Capítulo 3: Uma Luz para os Gentios. São Paulo: Cia das Letras, 2012.

ASLAN, R. Zelota: A Vida e a Época de Jesus de Nazaré. Rio de Janeiro: Zahar, 2013.

BROWN, R. E. Introdução ao Novo Testamento. São Paulo: Paulinas, 2004.

BULTMANN, R. Das Evangelium des Johannes. Göttingen: Vandenhoeck \& Ruprecht GmbH \& Co. KG, 2011.

CHEVITARESE, A. L.; FUNARI, P. P. A. Jesus Histórico: uma brevíssima introdução. Rio de Janeiro: Kline, 2012.

EHRMAN, B. Como Jesus se Tornou Deus. São Paulo: Leya, 2014. 
EHRMAN, B. O que Jesus Disse? O que Jesus Não Disse? Rio de Janeiro: Agir, 2006.

GIORGI, A. Alphabetum Thibetanum. Roma: Praefatio, 1742.

JOHNSON, P. História do Cristianismo. In: Parte Um: Ascensão e Resgate da Seita de Jesus (30-250). Rio de Janeiro: Imago, 2001.

JOSEFO, F. História dos Judeus. $8^{\underline{a}}$ ed. Rio de Janeiro: Casa Publicadora das Assembleias de Deus, 2004.

PLíNIO O VELHO. História Naturelle. Vol. 37. Paris: Les Belles Lettres, 1985.

SILVA, A. B. Resenha de Cristologia. Porto Alegre: Telecomunicação, 2008.

SUETÔNIO, C. T. A Vida Dos 12 Césares. Guarulhos: Germape, 2003.

SUFFERT, G. Tu És Pedro. In: Os Primórdios. Rio de Janeiro: Objetiva, 2001.

TÁCITO, C. Anais. Rio de Janeiro: Ediouro, s/d.

VANDENBERG, P. Nero: Imperador e Deus, Artista e Bufão. Rio de Janeiro: Zahar, 1981.

\section{APÊNDICE - REFERÊNCIAS DE NOTA DE RODAPÉ}

2. Nos 46 livros do AT existem poucas referências ao ato de orar, sendo encontrado, seis vezes: Salmos:4-3; 37-7; 65-02 e 66-18 - Provérbios 28:09; Isaías 65:24.

3. Salmos 148 não é uma profecia. É uma oração ao Senhor. O texto não é uma profecia, nem fala da existência de um Messias http://apocrifos2.blogspot.com/2011/09/o-evangelho-do-pseudo-mateus.html

4. Livro: Anais Capítulo: XV - 44, página, 248 - Caio Tácito comenta que Nero condenou à morte a seita dos cristãos e afirma que esses cristãos eram da cidade de Roma. 
5. Livro: Os 12 Césares, No Capítulo que trata sobre Nero, Suetônio afirmou que os cristãos foram jogados as feras. E sugere que; "gente dada a uma superstição inédita e perigosa".

6. Palavra de origem hebraica, que significa: pobre. Essa seita tinha como norma a união entre o judaísmo tradicional com os ensinamentos de Jesus. Para os Ebionistas, Jesus não veio abolir a Torá e sim cumprir. Eles afirmavam que tanto os gentios como os judeus deveriam cumprir com a Torá, neste caso, fazer a circuncisão.

7. Em Corinto, Paulo encontrou cristãos que reduziram Cristo a um mito. Em Colossenses, Paulo encontrou cristãos adorando: anjos e espíritos. Isso mostra o quão polimorfo eram os gnósticos. Eles mesclavam a filosofia platônica com a estória de Adão e Eva (JOHNSON, 2001, p. 60).

8. Vale a pena abrir um parêntese aqui. Os Evangelhos foram escritos após a queda de Jerusalém, em 73 d. C. Não existe nenhuma prova anterior a $65 \mathrm{~d}$. C, que Jesus havia profetizado a queda do Templo (nem as cartas de Paulo sustenta tal fato). Os autores dos Evangelhos usou a Queda do Templo para que o leitor possa se separar de vez do cristianismo do judaísmo rabínico.

9. A filha virgem (Ninsuna) do rei Sakharos foi encerrada em uma torre, para evitar uma concepção, mas foi fecundada por Shamash (deus do Sol) que chegou até ela, em forma de raios de sol.

10. Segundo Plínio, em sua "História Naturelle", diz que os cometas são astros que semeiam o terror.

11. Quando Israel era menino, eu o amei; e do Egito chamei a meu filho. Mas, como os chamavam assim se iam da sua face; sacrificavam a baalins, e queimavam incenso às imagens de escultura. Todavia, eu ensinei a andar a Efraim; tomando-os pelos seus braços, mas não entenderam que eu os curava.

12. Segundo sua monografia de 1941: Das Evangelium des Johannes que seria a base teológica para compreender o Jesus Histórico. 
Enviado: Abril, 2019.

Aprovado: Maio, 2020. 